\title{
The Effects of Ranitidine Treatment on the Risk of Necrotizing Enterocolitis in Preterm Infants: A Case-Control Study
}

\author{
Zlatan Zvizdic ${ }^{1}$, Emir Milisic ${ }^{1}$, Asmir Jonuzi ${ }^{1}$, Sabina Terzic² ${ }^{2}$ Denisa Zvizdic ${ }^{3}$, Semir Vranic ${ }^{4,5}$,*
}

\begin{abstract}
Introduction: Gastric acidity plays an important role in the protection of infants against various pathogens from the environment. The histamine-2 receptor blockers (H2-blockers) are off-labeled drugs that are frequently prescribed in preterm neonates to prevent stress ulcers. The impact of the H2-blockers on the development of the necrotizing enterocolitis (NEC) in preterm infants is still controversial, particularly in the developing world.

Materials and Methods: One hundred twenty-two preterm infants were enrolled in the study. The multivariate logistic regression model was used to identify potential postnatal risk factors associated with NEC.

Results: Preterm infants $(\mathrm{n}=51)$ with total NEC, medical NEC, and surgical NEC had the highest rate of receiving ranitidine compared with controls $(n=71)(39.2 \%, 19.6 \%$, and $47.6 \%, p<0.05)$. Logistic regression analysis revealed that ranitidine use and nosocomial infections were significantly associated with NEC development (odds ratios 1.55 and 3.3).

Conclusions: We confirm that ranitidine administration was associated with an increased risk of NEC in preterm infants. H2-blockers use should be only administered in very strictly selected cases after careful consideration of the risk-benefit ratio.
\end{abstract}

\section{KEYWORDS}

ranitidine; necrotizing enterocolitis; preterm infants; developing countries

AUTHOR AFFILIATIONS

${ }^{1}$ Clinic of Pediatric Surgery, University Clinical Center Sarajevo, Sarajevo, Bosnia and Herzegovina

2 Pediatric Clinic, Neonatal Intensive Care Unit, University Clinical Center Sarajevo, Sarajevo, Bosnia and Herzegovina

${ }^{3}$ Eye Clinic, Department of Pediatric Ophthalmology, University Clinical Center Sarajevo, Sarajevo, Bosnia and Herzegovina

${ }^{4}$ College of Medicine, QU Health, Qatar University, Doha, Qatar

${ }^{5}$ Biomedical and Pharmaceutical Research Unit, QU Health, Qatar University, Doha, Qatar

* Corresponding author: College of Medicine, QU Health, Qatar University, PO Box 2713, Doha, Qatar, e-mail: semir.vranic@gmail.com or svranic@qu.edu.qa

Received: 17 July 2020

Accepted: 26 November 2020

Published online: 14 April 2021

Acta Medica (Hradec Králové) 2021; 64(1): 8-14

https://doi.org/10.14712/18059694.2021.2

(c) 2021 The Authors. This is an open-access article distributed under the terms of the Creative Commons Attribution License (http://creativecommons.org/licenses/by/4.0), which permits unrestricted use, distribution, and reproduction in any medium, provided the original author and source are credited. 


\section{INTRODUCTION}

Despite many advances in the treatment of vulnerable preterm infants, necrotizing enterocolitis (NEC) remains the most common gastrointestinal tract emergency in the neonatal period with a substantial morbidity and a mortality rate (1-3). These rates may be substantially higher in developing countries (4-7). The well-established risk factor for NEC is prematurity while bowel ischemia, enteral feeding, and bacterial colonization pose an additional risk (8).

Prescription of inhibitors of gastric acid secretion (IGAS)/histamine-2 receptor blockers (H2-blockers) in preterm infants has been a widespread practice in the neonatal intensive care units (NICUs) because H2-blockers may prevent the gastric bleeding. The bleeding is usually caused by septic shock, hypotension, ischemia, and drugs such as indomethacin and corticosteroids (9). However, an increasing evidence suggests that some external factors including those that reduce gastric $\mathrm{pH}$ may affect the gastrointestinal bacterial milieu and thus predispose premature infants to inflammatory bowel disorder (10). Gastric acidity is considered a major non-immune defense barrier against infections in neonates through the reduction of the number of ingested bacteria. It consequently reduces the possibility of bacterial dissemination into the bloodstream via an immature and leaky gut barrier (11). Hence, the pathophysiological mechanism responsible for gastrointestinal bacterial overgrowth prompting infections may be triggered by blockade of gastric acid secretion by administration the $\mathrm{H} 2$-blockers (e.g., ranitidine, cimetidine) and proton pump inhibitors (PPIs; e.g., omeprazole). Bacterial overgrowth and infections due to an inefficient elimination of ingested pathogens are more common if gastric acidity is suppressed and the gastric $\mathrm{pH}$ rises above 4.0 (12-15). Since bacterial colonization and translocation are some of the important mechanisms in the pathogenesis of NEC, it is understandable the finding of some studies that the use of H2-blockers may predispose the development of NEC (16-18). Notably, Singh et al. could not confirm an association between $\mathrm{H} 2$-blockers administration and an increased risk of infection and NEC in preterm infants (19).

Several other risk factors for the NEC development in the neonatal intensive care units (NICU) have been reported including the use of invasive respiratory support (20), administration of morphine sulfate (21), the presence of circulation impairment requiring inotropic drug administration (22), erythrocyte transfusions (23), and nosocomial infections (24).

The data related to NEC are limited from resource-limited countries where the burden of infection is often the highest (25). In this context, we investigated the relationship between $\mathrm{H} 2$-blockers use and the development of NEC in a pediatric population originating from a middle-income population (Bosnia and Herzegovina). In addition, we explored other potential postnatal risk factors associated with NEC using multivariate logistic regression.

\section{PATIENTS AND METHODS}

\section{PATIENTS AND SELECTION CRITERIA}

We conducted a case-control study at the level III neonatal intensive care unit (NICU) of the University Clinical Center Sarajevo (Bosnia and Herzegovina), on 122 preterm infants classified into NEC group and control group. All patients were treated in the period 2008-2012. Sixty-seven (55\%) of infants were born at our obstetrics department while the remaining 55 patients (45\%) were transferred from other hospitals, typically (98\%) within 24 hours following the birth.

NEC group included 51 consecutive preterm infants treated for NEC $\geq$ stage II. Based on the severity of the disease, the NEC group was further divided into medical NEC and surgical NEC groups. A randomly selected control group $(\mathrm{N}=71)$ was formed from preterm infants without NEC whose clinical features were similar to those in the exposed group. The control group was treated in the same period as the NEC group (2008-2012).

The eligibility criteria were gestational age at delivery $<37$ weeks of gestation and diagnosis of NEC $\geq$ stage II, defined according to modified Bell's staging criteria (26). Gestational age was determined by an early ultrasound and recorded as completed weeks. A preterm birth was defined as any birth before 37 weeks of gestation or fewer than 259 days since the first day of the woman's last menstrual period. Medical NEC was defined as NEC that met Bell stage IIA, IIB, or IIIA criteria (26). Surgical NEC was defined as NEC requiring a surgical treatment and met Bell stage IIIB criteria (Supplemental Table 1). The infants were ineligible if they had major congenital anomalies, congenital heart disease, and gastrointestinal disorders that required surgery. The preterm infants who developed infection or NEC within 48 hours after receiving ranitidine were also excluded from the study.

The ranitidine was administered intravenously to all patients using our in house protocol: for term infants: $1.5 \mathrm{mg} / \mathrm{kg} /$ dose every 8 hours and for preterm infants at $0.5 \mathrm{mg} / \mathrm{kg} /$ dose every 12 hours. All patients were treated with ranitidine 5-7 days (mean: 6.15 days). The treatment with ranitidine was immediately terminated if the risk of complications (infections, NEC) would appear (mean: 56.2 hours following the initiation with ranitidine, range: 28-84 hours). A neonatologist made the decision for ranitidine use. The indications for ranitidine use included prevention and treatment of potential digestive tract bleeding, primarily gastric bleeding confirmed by blood-stained aspirate from nasogastric tube.

Nosocomial infection was defined as an infection that occurs after 48 hours following birth, resulting in a positive blood, cerebrosinal fluid, or urine culture with clinical manifestation such as hospital-aquired bloodstream infection, nosocomial pneumonia, sepsis, urinary tract infection, and meningitis.

The infants' medical records were reviewed daily for medical course information until hospital discharge or death of an infant. A standardized form was used for data collection. All medical records were anonymized for the study purposes. 
Institutional Review Board (IRB) of University Clinical Center Sarajevo approved the study (Number of approval: 0305-11118/2010) and waived informed consent request given the non-interventional nature of the study. All procedures performed in studies involving human participants were in accordance with the ethical standards of the IRB and with the 1964 Helsinki declaration and its later amendments or comparable ethical standards.

\section{STATISTICAL ANALYSIS}

Descriptive statistics were used to characterize the patients' cohort. The association between H2-blockers use and NEC was evaluated using Chi-square test. Preterm infants with NEC were compared on their relative odds by using multivariate logistic regression. A multiple logistic regression analysis was then used to identify potential postnatal risk factors associated with the development of NEC. The results were expressed as odds ratios (ORs) and 95\% confidence intervals (CIs). Statistical analysis was performed using Statistical Package for the Social Sciences (SPSS) IBM Version 26 (SPSS) (UNICOM Systems, Inc.). $P$-values $<0.05$ were considered significant.

\section{RESULTS}

Demographic data and clinical characteristics of the cohort are summarized in Table 1.

The mean gestational age of the total NEC group, medical and surgical NEC group and control group were similar. There were also no statistically significant differences between the groups concerning sex and mode of delivery ( $p>0.05$ ). The Apgar score reported at 1 minute in infants of the study and control groups was $5.3 \pm 2.3$ and $6.1 \pm 1.8$, respectively, and the difference was of the borderline significance $(p=0.05)$. The five-minute Apgar score in infants in the surgical NEC group was also significantly higher compared with the control group $(p=0.03)$. We also observed differences in the birth weight between the two groups $(p=0.02)$, particularly between the medical NEC subgroup and control infants $(\mathrm{p}=0.001)$.

Among infants with NEC, the medical NEC was diagnosed in 30 patients $(58.8 \%)$, while 21 patients were in the group of surgical NEC (41.2\%). Postnatal age at a time of appearance of NEC was 18.2 days (SD 12.8 days, range 2-57 days) while $49 \%$ of infants were older than 2 weeks. The patients were breastfed in a majority of cases (40/51).

Tab. 1 Demographic and clinical characteristics of the cohort.

\begin{tabular}{|c|c|c|c|c|c|c|c|c|}
\hline & $\begin{array}{l}\text { Total NEC } \\
n=51\end{array}$ & $\begin{array}{l}\text { Control } \\
\text { group } \\
n=71\end{array}$ & $\begin{array}{l}\text { Medical } \\
\text { NEC } \\
n=30\end{array}$ & $\begin{array}{l}\text { Surgical } \\
\text { NEC } \\
n=21\end{array}$ & $\begin{array}{l}\text { p1 } \\
\text { Total NEC } \\
\text { vs. Control } \\
\text { group }\end{array}$ & $\begin{array}{l}\text { p2 } \\
\text { Medical NEC } \\
\text { vs. Control } \\
\text { group }\end{array}$ & $\begin{array}{l}\text { p3 } \\
\text { Surgical NEC } \\
\text { vs Control } \\
\text { group }\end{array}$ & $\begin{array}{l}\text { p4 } \\
\text { Medical NEC } \\
\text { vs. Surgical } \\
\text { NEC group }\end{array}$ \\
\hline $\begin{array}{l}\text { Mean GA age } \\
\text { at birth/weeks } \\
(\text { Mean } \pm \text { SD) }\end{array}$ & $30.2 \pm 3.7$ & $30.9 \pm 2.7$ & $29.8 \pm 3.2$ & $30.6 \pm 4.3$ & NS & NS & NS & NS \\
\hline $\begin{array}{l}\text { Mean birth } \\
\text { weight/g (g) } \\
\text { Mean } \pm \text { SD }\end{array}$ & $\begin{array}{l}1502.7 \pm \\
781.5\end{array}$ & $\begin{array}{l}1609.8 \pm \\
459.3\end{array}$ & $\begin{array}{l}1316.7 \pm \\
574.3\end{array}$ & $\begin{array}{l}1768.6 \pm \\
960.4\end{array}$ & $p=0.02^{*}$ & $p=0.001^{*}$ & NS & NS \\
\hline Gender (M:F) (n) & $30 / 21$ & $39 / 32$ & $14 / 16$ & $16 / 5$ & NS & NS & NS & NS \\
\hline $\begin{array}{l}\text { Type of delivery } \\
\text { Vaginal / } \\
\text { Caesarian (n) }\end{array}$ & $33 / 18$ & $36 / 35$ & $17 / 13$ & $16 / 5$ & NS & NS & NS & NS \\
\hline $\begin{array}{l}\text { APGAR } 1 \\
\text { Mean } \pm \text { SD }\end{array}$ & $5.3 \pm 2.3$ & $6.1 \pm 1.8$ & $5.3 \pm 2.2$ & $5.1 \pm 2.4$ & $p=0.05^{*}$ & NS & NS & NS \\
\hline $\begin{array}{l}\text { APGAR } 5 \\
\text { Mean } \pm \text { SD }\end{array}$ & $6.3 \pm 1.8$ & $6.8 \pm 1.4$ & $6.5 \pm 1.9$ & $5.9 \pm 1.8$ & NS & NS & $p=0.03^{*}$ & NS \\
\hline $\begin{array}{l}\text { Antenatal ster- } \\
\text { oids } \\
\text { (yes/no) }\end{array}$ & $13 / 38$ & $21 / 50$ & $11 / 19$ & $2 / 19$ & $\begin{array}{l}p=0.6209 \\
\text { NS }\end{array}$ & $\begin{array}{l}p=0.2904 \\
\text { NS }\end{array}$ & $\begin{array}{l}p=0.1321 \\
N S\end{array}$ & $p=0.0302^{*}$ \\
\hline $\begin{array}{l}\text { IUGR } \\
\text { (yes/no) }\end{array}$ & $7 / 44$ & $4 / 67$ & $5 / 25$ & $2 / 19$ & $\begin{array}{l}p=0.1253 \\
\text { NS }\end{array}$ & $\begin{array}{l}p=0.0768 \\
\text { NS }\end{array}$ & $\begin{array}{l}p=0.5282 \\
\text { NS }\end{array}$ & $\begin{array}{l}p=0.4701 \\
N S\end{array}$ \\
\hline $\begin{array}{l}\text { PDA } \\
\text { (yes/no) }\end{array}$ & $14 / 37$ & $3 / 68$ & $9 / 21$ & $5 / 16$ & $p=0.0003^{*}$ & $\begin{array}{l}p=0.8071 \\
\text { NS }\end{array}$ & $\begin{array}{l}p=0.7517 \\
\text { NS }\end{array}$ & $\begin{array}{l}p=0.6293 \\
N S\end{array}$ \\
\hline $\begin{array}{l}\text { Length of hospi- } \\
\text { tal stay } \pm \text { SD }\end{array}$ & $49.6 \pm 36.3$ & $35.6 \pm 20.5$ & $48.5 \pm 32.2$ & $51.2 \pm 42.2$ & $p=0.0180^{*}$ & $p=0.0310^{*}$ & $p=0.0379^{*}$ & NS \\
\hline $\begin{array}{l}\text { Mortality rate } \\
\text { (Death/Total) }\end{array}$ & $\begin{array}{l}0.333 \\
(17 / 51)\end{array}$ & $\begin{array}{l}0.0986 \\
(7 / 71)\end{array}$ & $\begin{array}{l}0.1667 \\
(5 / 30)\end{array}$ & $\begin{array}{l}0.5714 \\
(12 / 21)\end{array}$ & $p=0.0039^{*}$ & $p=0.3644$ & $p<0.0001^{*}$ & $p=0.013^{*}$ \\
\hline
\end{tabular}

* Significant $p$-values $(p<0.05)$

$\mathrm{NS}=$ non-significant $p$-value; $\mathrm{SD}=$ standard deviation; NEC = necrotizing enterocolitis. 
Tab. 2 Potential postnatal risk factors associated with the development of necrotizing enterocolitis in preterm infants.

\begin{tabular}{|l|l|l|l|}
\hline Variable & OR & $\mathbf{9 5 \%}$ Cl & P-value* \\
\hline H2-blockers & 1.5503 & $1.0514-2.2861$ & $\mathbf{0 . 0 3}$ \\
\hline Nosocomial infections & 3.3169 & $1.0993-10.0086$ & $\mathbf{0 . 0 3}$ \\
\hline Intubation and ventilation & 1.1848 & $0.9671-1.4515$ & 0.10 \\
\hline Nasal continuous positive airway pressure & 0.9117 & $0.7618-1.0911$ & 0.31 \\
\hline Morphine sulfate & 1.8500 & $0.9242-3.7031$ & 0.08 \\
\hline Inotropes & 0.9621 & $0.6542-1.4148$ & 0.84 \\
\hline Red blood cell transfusions & 0.6474 & $0.3022-1.3870$ & 0.26 \\
\hline
\end{tabular}

* Only significant variables were bolded.

$\mathrm{OR}=$ odds ratio; $\mathrm{Cl}=$ confidence interval; $\mathrm{H} 2$-blockers = histamine-2 receptor blockers.

No baby was fed by a donor breast milk. Consequently, we have not observed any differences between study groups related to the type of enteral feed. In one patient, NEC developed before starting of enteral feeding. The most common gastrointestinal symptoms were abdominal distension (89\%), gross or microscopic blood in the stool (56.9\%) and increasing gastric residuum (46\%).

During the study period, 20/51 (39.2\%) preterm infants with NEC received H2-blockers, whereas only $6 / 71$ (8.5\%) preterm infants in the control group received $\mathrm{H} 2$-blockers ( $p<0.001$ ). Among NEC cases, 10/30 (33.3\%) preterm infants with medical NEC and 10/21 (47.6\%) infants with surgical NEC received H2-blockers (Figure 1). We also found a statistically significant association between $\mathrm{H} 2$-blockers use and NEC in both medical and surgical NEC groups in comparison with the control group $(p=0.005, p=0.0001$, respectively). In contrast, no significant difference was found between medical and surgical NEC subgroups regarding the H2-blockers use and the development of NEC $(\mathrm{p}=0.41)$.

The results of the conditional logistic regression model using seven independent variables (H2-blockers, nosocomial infections, intubation and ventilation, nasal continuous positive airway pressure, morphine sulfate, inotropes, and red blood cell transfusions) showed that the

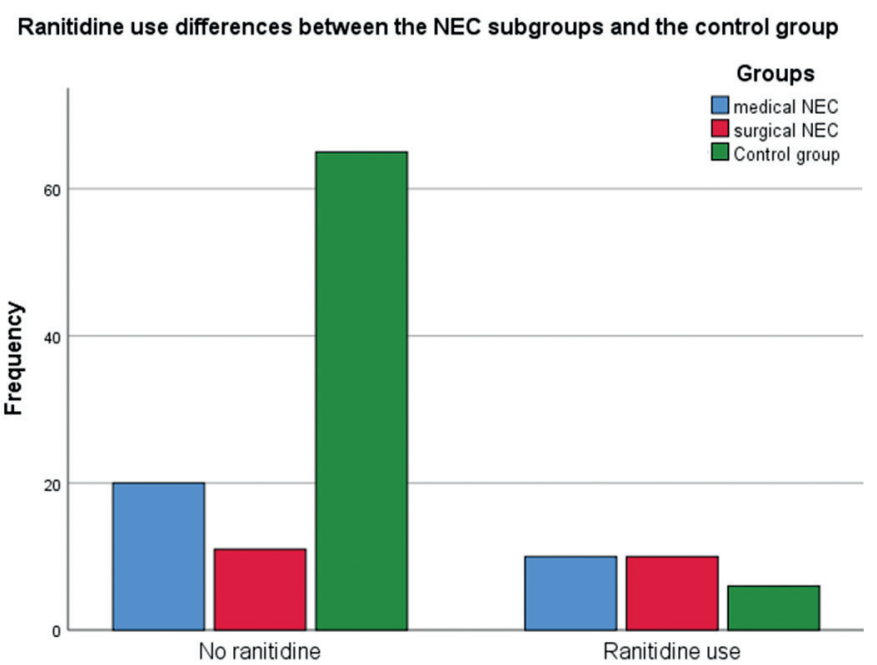

Fig. 1 Differences in the frequency of preterm infants receiving H2-blockers therapy. model was statistically significant $(p<0.001)$. This model could reliably predict the patients with a higher likelihood of developing NEC. H2-blockers use was associated with an increased incidence of NEC (Table 2). In addition, nosocomial infections were significantly associated with the development of NEC (Table 2).

\section{DISCUSSION}

NEC remains the most common gastrointestinal tract emergency in the neonatal period with a significant morbidity and mortality $(2,3,27)$. Our study confirms the association between the use of $\mathrm{H} 2$-blockers use and NEC. Previous studies have also provided similar conclusions regarding the use of $\mathrm{H} 2$-blockers and NEC development $(17,18,28-30)$. In a large cohort of $>11,000$ very low birth weight (VLBW) infants, Guillet et al. suggested an association between the use of H2-blockers and NEC revealing that treatment with $\mathrm{H} 2$-blockers was associated with a higher incidence of NEC (28). Similarly, Terrin et al. in prospective study of 309 VLBW infants reported that ranitidine use was associated with increased risk of infection, NEC, and overall mortality (17). Bilali et al. in a case-control study that included 116 preterm infants with NEC reported that H2-blocker therapy was significantly associated with an increased incidence of NEC (30). Another evidence-based survey of Chandrasekaran and Fleming further confirmed that the use of ranitidine/H2 blockers is associated with an increased incidence of NEC (level 2b = individual cohort studies and low-quality randomized control trials) (31).

A recent systematic review with meta-analysis exploring the impact of H2-blockers use in neonates in NICUs on infections, NEC and mortality revealed that these drugs might increase the risk of infections and NEC in neonates. Consequently, the use of $\mathrm{H} 2$-blockers in neonates must be stringently considered only when necessary (32). Another systematic review by Green et al., based on 11 studies involving $>800$ preterm and term neonates confirmed the efficacy of $\mathrm{H} 2$-blockers in preventing gastrointestinal bleeding. Given that no single study reported the incidence of NEC, the authors concluded that the safety of $\mathrm{H} 2$-blockers in this regard remained unclear (33).

In contrast to the numerous studies that have reported an association between H2-blockers use and NEC, 
a retrospective study of Singh et al. reported that the use of ranitidine/omeprazole was not associated with adverse outcomes of late sepsis, NEC, and mortality in VLBW neonates (< 1500 grams) (19). The authors also emphasized the importance of the age at which ranitidine was commenced, suggesting that the administration of ranitidine and omeprazole in the later postnatal age of premature infants born $<1500$ grams ( 37 days and 72 days after birth, respectively) allows for development and maturation of the immune system, thus reducing susceptibility to late onset sepsis or NEC (19). Interestingly, a systematic review on risk factors for NEC conducted by Samuels et al. did not reveal commonly assumed clinical neonatal risk factors for NEC such as central lines, red cell transfusions, H2-blockers, and a high osmolar formula feeding as important prognostic factors (34). A possible explanation for such findings may lie in the fact that the analyzed studies were not prognostic.

One of the relevant findings in our study is the impact of nosocomial infections on the NEC development among the preterm infants (35). A four-fold increase in the risk of bloodstream infection among the NICU infants who received $\mathrm{H2}$-blockers was noted in the prospective study conducted by Beck-Sague et al. (36). Another study that included 91 children undergoing gastroesophageal reflux disease (GERD) treatment with gastric acidity inhibitors found an increased risk of intestinal and respiratory infectious diseases compared with 95 non-treated patients (14). Similarly, Graham et al. showed that H2-blockers use might increase the risk of infection in low birth weight (LBW) infants (37). The mechanisms by which H2-blockers use may contribute to the increase risk of NEC have not been clarified yet. It is well known that a significant function of gastric acidic juice is the inactivation of ingested microorganisms within a few minutes at $\mathrm{pH}<3$ in addition to protein denaturation, activation of pepsinogen and augmentation of intestinal absorption of iron, calcium, and vitamin B12 (38). The proposed mechanism of association between $\mathrm{H} 2$-blockers use and NEC in preterm infants is a loss of gastric acidity that causes an increased bacterial colonization of GI tract and consequently leads to the increased risk of preterm infants to gram-negative and opportunistic infections (17). It should be noted that the reasons for effects of ranitidine administration are not limited only to the reduction of gastric $\mathrm{pH}$ but also to an increase the production of pro-inflammatory cytokines and reduce immunological responses to infection (37). It is worth mentioning that the time for bacterial/substrate interaction is also increased due to reduced intestinal motility in preterm infants thus facilitating bacterial overgrowth (39).

Considering all the above concerns, it is understandable that H2-blockers induced hypochlorhydria predisposes infants to the enteric infections including NEC. An additional risk factor associated with $\mathrm{H} 2$-blockers use is the finding that $\mathrm{H} 2$-blockers strike down several functions of leukocytes, thereby leading to insufficient control of the production of inflammatory cytokines in the intestinal tract $(40,41)$. Since NEC is a multifactorial disease, it is unlikely that one factor (e.g. H2-blockers use) would

independently increase the overall incidence of NEC, but its use increases the risk of this devastating disease.

Our study had some limitations including the inherent errors and bias of retrospective nature of the study (conducted in the period 2008-2012), small sample size and restriction to a single pediatric surgical center, which may limit the generalizability of our conclusions. A further limitation of our study is related to the lack of accuracy in indications for the ranitidine use. It may be possible that infants with early NEC symptoms were treated with ranitidine before an accurate diagnosis of NEC was made. Therefore, larger prospective studies are required to confirm the effect of H2-blockers on susceptibility to infections and NEC in preterm infants. In all pediatric indications ranitidine should be very cautiously used given the recent recommendation from the regulatory bodies from Europe, US and Canada to withdraw ranitidine from the market. Namely, it has been found that N-nitrosodimethylamine (NDMA) levels in ranitidine products might exhibit potentially carcinogenic effects.

\section{CONCLUSIONS}

Our study from the middle-income country provides further evidence for a possible association and role of $\mathrm{H} 2$-blockers use and NEC development in preterm infants, suggesting that H2-blockers use should be only administered in strictly selected cases after careful consideration of the risk-benefit ratio.

\section{ABBREVIATIONS}

CI

FDA

GERD

GI

H2-blockers

IGAS

IUGR

LBW

NDMA

NEC

NICU

OR

PDA

PPI

SD

VLBW

\section{AUTHOR CONTRIBUTIONS}

Conceptualization and methodology, Z.Z. and S.V.; Formal analysis, Z.Z., E.M., A.J., S.T., D.Z..; Data curation, Z.Z., S.T., D.Z.; Writing - original draft preparation, Z.Z. and S.V..; Writing - review and editing, S.V. and Z.V..; Supervision, S.V. All authors have read and agreed to the published version of the manuscript. 
FUNDING

This research received no external funding.

\section{ACKNOWLEDGEMENTS}

None.

\section{CONFLICTS OF INTEREST}

\section{The authors declare no conflict of interest.}

\section{REFERENCES}

1. Fitzgibbons SC, Ching Y, Yu D, Carpenter J, et al. Mortality of necrotizing enterocolitis expressed by birth weight categories. J Pediatr Surg 2009; 44(6): 1072-5; discussion 5-6.

2. Frost BL, Modi BP, Jaksic T, Caplan MS. New Medical and Surgical Insights Into Neonatal Necrotizing Enterocolitis: A Review. JAMA Pediatr 2017; 171(1): 83-8.

3. Alganabi M, Lee C, Bindi E, Li B, Pierro A. Recent advances in understanding necrotizing enterocolitis. F1000Res 2019; 8: F1000 Faculty Rev-107.

4. Arnold M, Moore SW, Sidler D, Kirsten GF. Long-term outcome of surgically managed necrotizing enterocolitis in a developing country. Pediatr Surg Int 2010; 26(4):355-60.

5. Sheng $\mathrm{Q}, \mathrm{Lv} \mathrm{Z}$, Xu W, et al. Short-term surgical outcomes of preterm infants with necrotizing enterocolitis: A single-center experience. Medicine (Baltimore) 2016; 95(30): e4379.

6. Lin H, Mao S, Shi L, Tou J, Du L. Clinical characteristic comparison of low birth weight and very low birth weight preterm infants with neonatal necrotizing enterocolitis: a single tertiary center experience from eastern China. Pediatr Surg Int 2018; 34(11): 1201-7.

7. Deshpande G, Jape G, Rao S, Patole S. Benefits of probiotics in preterm neonates in low-income and medium-income countries: a systematic review of randomised controlled trials. BMJ Open 2017; 7(12): e017638.

8. Neu J, Walker WA. Necrotizing enterocolitis. N Engl J Med 2011; 364(3): 255-64.

9. Kuusela AL, Ruuska T, Karikoski R, et al. A randomized, controlled study of prophylactic ranitidine in preventing stress-induced gastric mucosal lesions in neonatal intensive care unit patients. Crit Care Med 1997; 25(2): 346-51.

10. Bergholz TM, Whittam TS. Variation in acid resistance among enterohaemorrhagic Escherichia coli in a simulated gastric environment. J Appl Microbiol 2007; 102(2): 352-62.

11. Martinsen TC, Bergh K, Waldum HL. Gastric juice: a barrier against infectious diseases. Basic Clin Pharmacol Toxicol 2005; 96(2): 94-102.

12. Dial MS. Proton pump inhibitor use and enteric infections. Am J Gastroenterol 2009; 104(Suppl 2): S10-6.

13. Canani RB, Terrin G. Gastric acidity inhibitors and the risk of intestinal infections. Curr Opin Gastroenterol 2010; 26(1): 31-5.

14. Canani RB, Cirillo P, Roggero P, et al. Therapy with gastric acidity inhibitors increases the risk of acute gastroenteritis and community-acquired pneumonia in children. Pediatrics 2006; 117(5): e817-20.

15. Terrin G, Canani RB, Passariello A, Caoci S, De Curtis M. Inhibitors of gastric acid secretion drugs increase neonatal morbidity and mortality. J Matern Fetal Neonatal Med 2012; 25(Suppl 4): 85-7.

16. Patole S. Association of H2-blocker therapy and higher incidence of necrotizing enterocolitis: a case of excessive collateral damage? Pediatrics 2006; 117(2): 531-2.

17. Terrin G, Passariello A, De Curtis M, et al. Ranitidine is associated with infections, necrotizing enterocolitis, and fatal outcome in newborns. Pediatrics 2012; 129(1): e40-5.

18. More K, Athalye-Jape G, Rao S, Patole S. Association of inhibitors of gastric acid secretion and higher incidence of necrotizing enterocolitis in preterm very low-birth-weight infants. Am J Perinatol 2013; 30(10): 849-56.

19. Singh N, Dhayade A, Mohamed AL, Chaudhari TV. Morbidity and Mortality in Preterm Infants following Antacid Use: A Retrospective Audit. Int J Pediatr 2016; 2016: 9649162.

20. Havranek T, Thompson Z, Carver JD. Factors that influence mesenteric artery blood flow velocity in newborn preterm infants. J Perinatol 2006; 26(8): 493-7.

21. Zvizdic Z, Milisic E, Jonuzi A, Terzic S, Zvizdic D. The contribution of morphine sulfate to the development of necrotizing enterocolitis in preterm infants: a matched casecontrol study. Turk J Pediatr 2019; 61(4): 513-9.

22. Gephart SM, Spitzer AR, Effken JA, Dodd E, Halpern M, McGrath JM. Discrimination of GutCheck(NEC): a clinical risk index for necrotizing enterocolitis. J Perinatol 2014; 34(6): 468-75.

23. Mohamed A, Shah PS. Transfusion associated necrotizing enterocolitis: a meta-analysis of observational data. Pediatrics 2012; 129(3): 529-40.

24. Alidjinou EK, Lazrek M, Schuffenecker I, et al. Necrotizing Enterocolitis Cases Associated with Nosocomial Enterovirus Transmission in a Neonatal Unit. Pediatr Infect Dis J 2018; 37(9): 954-7.

25. Santana RNS, Santos VS, Ribeiro-Junior RF, et al. Use of ranitidine is associated with infections in newborns hospitalized in a neonatal intensive care unit: a cohort study. BMC Infect Dis 2017; 17(1): 375.

26. Walsh MC, Kliegman RM. Necrotizing enterocolitis: treatment based on staging criteria. Pediatr Clin North Am 1986; 33(1): 179-201.

27. Eaton S, Rees CM, Hall NJ. Current Research on the Epidemiology, Pathogenesis, and Management of Necrotizing Enterocolitis. Neonatology 2017; 111(4): 423-30.

28. Guillet R, Stoll BJ, Cotten CM, et al. Association of H2-blocker therapy and higher incidence of necrotizing enterocolitis in very low birth weight infants. Pediatrics. 2006; 117(2): e137-42.

29. Lin HC, Su BH, Chen AC. H2-blocker therapy and necrotizing enterocolitis for very low birth weight preterm infants. Pediatrics 2006; 118(4): 1794-5; author reply 5-6.

30. Bilali A, Galanis P, Bartsocas C, Sparos L, Velonakis E. H2-blocker therapy and incidence of necrotizing enterocolitis in preterm infants: a case-control study. Pediatr Neonatol 2013; 54(2): 141-2.

31. Chandrasekaran M, Fleming P. Question 1: does the use of ranitidine increase the risk of NEC in preterm infants? Arch Dis Child 2014; 99(4):390-2.

32. Santos VS, Freire MS, Santana RNS, Martins-Filho PRS, Cuevas LE, Gurgel RQ. Association between histamine-2 receptor antagonists and adverse outcomes in neonates: A systematic review and meta-analysis. PloS One 2019; 14(4): e0214135.

33. Green DS, Abdel-Latif ME, Jones LJ, Lui K, Osborn DA. Pharmacological interventions for prevention and treatment of upper gastrointestinal bleeding in newborn infants. Cochrane Database Syst Rev 2019; 7: CD011785.

34. Samuels N, van de Graaf RA, de Jonge RCJ, Reiss IKM, Vermeulen MJ. Risk factors for necrotizing enterocolitis in neonates: a systematic review of prognostic studies. BMC Pediatrics 2017; 17(1): 105.

35. Zvizdic Z, Heljic S, Firdus A, Jonuzi A, Zvizdic D. Relationship of nosocomial infections with the development of necrotizing enterocolitis in preterm infants. Mater Sociomed 2014; 26(1): 4-6.

36. Beck-Sague CM, Azimi P, Fonseca SN, et al. Bloodstream infections in neonatal intensive care unit patients: results of a multicenter study. Pediatr Infect Dis J 1994; 13(12): 1110-6.

37. Graham PL, Begg MD, Larson E, Della-Latta P, Allen A, Saiman L. Risk factors for late onset gram-negative sepsis in low birth weight infants hospitalized in the neonatal intensive care unit. Pediatr Infect Dis J 2006; 25(2): 113-7.

38. Conroy S, McIntyre J. The use of unlicensed and off-label medicines in the neonate. Semin Fetal Neonatal Med 2005; 10(2): 115-22.

39. Neu J. Gastrointestinal maturation and implications for infant feeding. Early Hum Dev 2007; 83(12): 767-75.

40. Moharana AK, Bhattacharya SK, Mediratta PK, Sharma KK. Possible role of histamine receptors in the central regulation of immune responses. Indian J Physiol Pharmacol 2000; 44(2): 153-60.

41. van der Pouw Kraan TC, Snijders A, Boeije LC, et al. Histamine inhibits the production of interleukin-12 through interaction with $\mathrm{H} 2$ receptors. J Clin Invest 1998; 102(10): 1866-73. 
Supplemental Table 1 Modified Bell's staging criteria for necrotizing enterocolitis.

\begin{tabular}{|l|l|l|l|}
\hline Stage & Systemic signs & Abdominal signs & Radiographic signs \\
\hline IA suspected & $\begin{array}{l}\text { Temperature instability, apnea, } \\
\text { bradycardia, lethargy }\end{array}$ & $\begin{array}{l}\text { Gastric retention, abdominal } \\
\text { distention, emesis, heme-posi- } \\
\text { tive stool }\end{array}$ & $\begin{array}{l}\text { Normal or intestinal dilation, } \\
\text { mild ileus }\end{array}$ \\
\hline IB suspected & Same as above & Grossly bloody stool & Same as above \\
\hline IIA definite, mildly ill & Same as above & $\begin{array}{l}\text { Same as above, plus absent } \\
\text { bowel sounds with or without } \\
\text { abdominal tenderness }\end{array}$ & $\begin{array}{l}\text { Intestinal dilation, ileus, pneu- } \\
\text { matosis intestinalis }\end{array}$ \\
\hline IIB definite, moderately ill & $\begin{array}{l}\text { Same as above, plus mild } \\
\text { metabolic acidosis and thrombo- } \\
\text { cytopenia }\end{array}$ & $\begin{array}{l}\text { Same as above, plus absent } \\
\text { bowel sounds, definite tender- } \\
\text { ness, with or without abdominal } \\
\text { cellulitis or right lower quadrant } \\
\text { mass }\end{array}$ & Same as IIA, plus ascites \\
\hline $\begin{array}{l}\text { IIIA advanced, severely ill, } \\
\text { intact bowel }\end{array}$ & $\begin{array}{l}\text { Same as IIB, plus hypotension, } \\
\text { bradycardia, severe apnea, com- } \\
\text { bined respiratory and metabolic } \\
\text { acidosis, DIC,and neutropenia }\end{array}$ & $\begin{array}{l}\text { Same as above, plus signs of } \\
\text { peritonitis, marked tenderness, } \\
\text { and abdominal distention }\end{array}$ & Same as IIA, plus ascites \\
\hline $\begin{array}{l}\text { IIIB advanced, } \\
\text { severely ill, } \\
\text { perforated } \\
\text { bowel }\end{array}$ & \begin{tabular}{l} 
Same as IIIA \\
\hline
\end{tabular} & Same as IIIA & $\begin{array}{l}\text { Same as above, plus pneumop- } \\
\text { eritoneum }\end{array}$ \\
\hline
\end{tabular}

